\title{
MAGNIFICATION ERROR IN RADIOGRAPHS OF CERVICAL SPINE IN LATERAL PROJECTION
}

\section{VELIKOST VRATNIH VRETENC V STRANSKI PROJEKCIJI}

\section{Ana Cesar, Manca Grkman, Mojca Medič*}

University of Ljubljana, Faculty of Health Sciences, Department of Medical Imaging and Radiotherapy, Zdravstvena pot 5, 1000 Ljubljana, Slovenia

*Corresponding author: mojca.medic@zf.uni-lj.si

Received: 26. 9. 2020

Accepted: 14. 4. 2020

https://doi.org/10.47724/MIRTJ.2020.i01.a003

\begin{abstract}
Purpose: The main purpose of this study was to determine how the distance between the cervical spine and the image receptor on the one hand and the distance between the source and the image receptor on the other affects the image size of the cervical vertebrae. Moreover, it was important to understand how the entrance skin dose varies when the distance between the object to image receptor and the distance source to image receptor changes.
\end{abstract}

Methods: The theoretical part of this study was carried out based on an analysis of the readings, the practical part was carried out on a head, neck and trunk phantom at the radiological laboratory of the Faculty of Health Sciences (University of Ljubljana).

Results: When the object to image receptor distance (OID) was increased from 24 to $39 \mathrm{~cm}$, the image size of the vertebra increased by $23 \%$ at a source to image receptor distance (SID) of $115 \mathrm{~cm}$. At an SID of $150 \mathrm{~cm}$, it increased by $17 \%$ and by $11 \%$ at an SID of $180 \mathrm{~cm}$. When SID was decreased from 150 to $115 \mathrm{~cm}$ at an OID of between of 24 and $29 \mathrm{~cm}$, the entrance skin dose increased by $26 \%$. As the OID was increased further, the entrance skin dose (ESD) was even higher. Similarly, the ESD decreased with an increase in SID. For example, when SID was increased from 150 to $180 \mathrm{~cm}$ at an OID of between 24 and $29 \mathrm{~cm}$, the ESD decreases by $8.5 \%$.

Discussion and conclusion: The results indicate that the lateral radiography of the cervical spine should be performed at a SID of $150 \mathrm{~cm}$. By doing so, it is assured that a proper image size is obtained, and the entrance skin dose is not harmful to the patient.

Keywords: source to image receptor distance (SID), object to image receptor distance (OID), lateral radiography of the cervical spine, entrance skin dose (ESD)

\section{IZVLEČEK}

Namen: Želeli smo ugotoviti, kako oddaljenost vratnih vretenc od slikovnega sprejemnika in oddaljenost gorišča od slikovnega sprejemnika vplivata na velikost vratnih vretenc na rentgenogramu in vstopno kožno dozo pri slikanju vratne hrbtenice v stranski projekciji.

Metode dela: $\mathrm{V}$ teoretičnem delu smo podatke pridobili z deskriptivno metodo, s čimer smo želeli preučiti obstoječo literaturo. Podatke za praktičen del smo pridobili s pomočjo eksperimentalne metode raziskovanja, na podlagi meritev na fantomu glave, vratu in trupa $v$ radiološkem laboratoriju Zdravstvene fakultete Univerze v Ljubljani.

Rezultati: Pri povečanju razdalje objekt-slikovni sprejemnik (ROS) iz 24 na $39 \mathrm{~cm}$ se vretence pri razdalji gorišče-slikovni sprejemnik (RGS) $115 \mathrm{~cm}$ poveča za $23 \%$, pri RGS 150 in $180 \mathrm{~cm}$ pa za $17 \%$ in $11 \%$. Pri zmanjšanju RGS iz 150 na $115 \mathrm{~cm}$, pri ROS med 24 in 29 cm, se vstopna kožna doza (VKD) poveča za $26 \%$, pri ROS med 30 in $34 \mathrm{~cm}$, za $31 \%$, pri ROS med 35 in $39 \mathrm{~cm}$ za 35 $\%$. Pri zvečanju razdalje RGS iz 150 na $180 \mathrm{~cm}$, pri ROS 24 do 29 cm, se VKD zmanjša za 8,5 \%, pri ROS med 30 in 34 cm, za 11,6\%, pri ROS od 35 do $39 \mathrm{~cm}$ za 12,5\%.

Razprava in zaključek: Meritve so pokazale, da je priporočljivo stransko slikanje vratne hrbtenice na razdalji RGS $150 \mathrm{~cm}$ ustrezno iz dveh razlogov: z večjo RGS vplivamo na manjšo povečavo objekta na rentgenogramu in hkrati zmanjšamo vstopno kožno dozo pacientu.

Ključne besede: razdalja gorišče-slikovni sprejemnik (RGS), razdalja objekt-slikovni sprejemnik (ROS), slikanje vratne hrbtenice stransko, vstopna kožna doza (VKD) 


\section{INTRODUCTION}

Lateral radiography of the cervical spine (X-ray) is a basic diagnostic examination. The basic projections are the anteroposterior (AP) and lateral projections, which show possible pathological changes (1). When imaging the cervical spine laterally, the anatomical features of the imaging area and the physical properties of the X-ray beam must be taken into account in order to achieve an optimal and diagnostically useful radiograph. Important parameters that must be taken into account are the following: source to image receptor distance (SID), object to image receptor distance (OID) and source to object distance (SOD). They impact the distortion of an object in a radiograph (2).

\section{Factors that impact the image quality}

Distortion is the incorrect display of the size and form of an object in a radiograph. Due to the divergence of the X-ray beam, every object looks larger on a radiograph than its natural size (2). In order to achieve the lowest possible magnification, which affects the spatial resolution of the image, we must reduce the OID as much as possible and increase the $\operatorname{SID}(1,3)$. These parameters are particularly important in lateral imaging of the cervical spine, as cervical vertebrae cannot be adjacent to the image receptor due to the width of the shoulders. Since the object is distant from the image receptor due to anatomical properties, we can reduce the magnification on a radiograph by increasing SID from 115 to $150 \mathrm{~cm}$. Magnification factor can be calculated according to the formula below $(1,4)$ :

$$
\text { Magnification factor }(M f)=\frac{S I D}{S O D}=\frac{\text { object image size }}{\text { natural object size }}
$$

Two independent studies to address the magnification of the cervical vertebrae on a radiograph were conducted with the aim of determining the connection between the body mass index (BMI) and the magnification of cervical vertebrae in lateral projection. Both studies included body measurements of the second and fifth cervical vertebrae. The size of the cervical vertebrae on a radiograph were compared to their size on magnetic resonance (MR) and computed tomography (CT) images. Ravi and Rampersaud (5) included 250 patients in their analysis and discovered that there is a statistically significant correlation between the magnification of cervical vertebrae on a radiograph and BMI. Shigematsu et al. (6) conducted a study on 54 patients and did not identify a statistically significant correlation between the magnification of cervical vertebrae and BMI.

\section{Entrance skin dose}

Entrance skin dose (ESD) is defined as the absorbed dose measured on the central beam axis at the position of the patient or phantom surface. It is a sum of the direct radiation beam and backscattered radiation from the patient (7). ESD is calculated using the following formula:

$E S D=B S F($ backscatter factor $) \cdot Y($ tube output $) \cdot\left(\frac{100}{S O D}\right)^{2} \cdot 1 t$
When the voltage in the conduit and the product of tube current and time (It) remain constant, the radiation intensity decreases by the square of the distance. The increase in SID leads to a lower ESD. The automatic exposure control (AEC) system adjusts the exposure so that the signal-to-noise ratio remains the same, regardless of the accelerating voltage that is used to accelerate the electrons in the X-ray tube and regardless of the thickness of the imaging object. The AEC system adjusts the $\mathrm{mAs}$ product so that the radiation intensity on an image receptor remains the same, regardless of the changed distance of the image receptor from the source of radiation $(8,9)$.

Zdešar et al. (10) stated in their research report about the radiation of patients in ordinary radiographic examinations at the Slovenj Gradec General Hospital that an average ESD of the lateral imaging of the cervical spine remains the same, i.e. $0.98 \mathrm{mGy}$, at the SID of $115 \mathrm{~cm}$ to $145 \mathrm{~cm}$. The measurement was conducted on ten patients with an average weight of 74 $\mathrm{kg}$, using the AEC system.

A research conducted by Joyce et al. (11) aimed to determine the impact of SID on ESD. The AEC, a flat panel detector and accelerating voltage of $65 \mathrm{kV}$ were used. The source to image receptor distances used were $150 \mathrm{~cm}, 180 \mathrm{~cm}$ and $210 \mathrm{~cm}$. An increase in the distance from $150 \mathrm{~cm}$ to $210 \mathrm{~cm}$ led to a decrease in ESD by $37.4 \%$. The dose also decreased by $22.9 \%$ when the distance was increased from $150 \mathrm{~cm}$ to $180 \mathrm{~cm}$.

\section{AIM}

The aim of the study was to determine how the distance of the cervical vertebrae from the image receptor and the source to image receptor distance impact the size of the cervical vertebrae on the radiograph and entrance skin dose during the lateral imaging of the cervical spine.

The following research questions were raised:

1. Does the source to image receptor distance impact the size of vertebrae on a radiograph during the lateral imaging of the cervical spine?

2. Does the object to image receptor distance impact the size of vertebrae on a radiograph?

3. How does the entrance skin dose change at different source to image receptor distances?

\section{METHODS}

In the theoretical part, we obtained data using a descriptive method and studied existing literature. The data for the practical part were obtained using an experimental research method, based on the measurements on a head/neck/torso phantom in the radiology laboratory at the Faculty of Health Sciences, University of Ljubljana.

In order to make a connection with practical lateral imaging of the cervical spine, we chose a man with the broadest shoulders and a woman with the narrowest shoulders in the population of 40 students. They were placed against a tripod, in the same way as in the lateral projection of the cervical spine so that the shoulder was adjacent to the tripod. We measured the distance from the spinous process of the seventh cervical vertebra to the tripod. Based on the obtained measurements, we changed the object to image receptor distance by $1 \mathrm{~cm}$, from $24 \mathrm{~cm}$ to $39 \mathrm{~cm}$. 
The measurements were performed on a Siemens Multix/ Vertix X-ray machine, with the source size of $1 \mathrm{~mm}$ and total filtration of photon beam of $2.5 \mathrm{~mm}$ of aluminium (1.5 $\mathrm{mm} \mathrm{Al} \mathrm{own} \mathrm{filtration} \mathrm{and} 1 \mathrm{~mm} \mathrm{Al}$ additional filtration). The imaging was conducted against a Vertix wall tripod, with a grid ratio of 13:1, with 70 lamellae per centimetre where the optimum source to image receptor distance was $150 \mathrm{~cm}( \pm$ $20 \mathrm{~cm}$ ). We used the AEC system for imaging and chose an $\mathrm{X}$-ray tube voltage of $70 \mathrm{kV}$, according to the DIMOND III (12) recommendations.

We used a PBU 60 head/neck/torso phantom (Kyotokagaku Co., Ltd, Japan) with an attenuation coefficient, which equals a person of $165 \mathrm{~cm}$ in height and $50 \mathrm{~kg}$ in weight. It was placed against the tripod in the supine position. The central beam was placed at the height of the fourth cervical vertebra. The direction of the central beam was perpendicular to the vertebrae and CR plate (Figure 1).

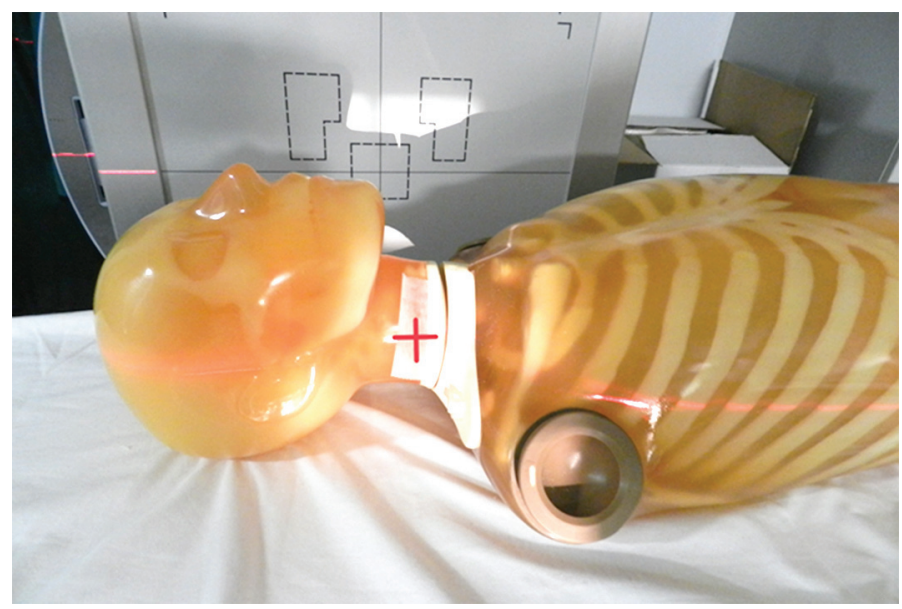

Figure 1: PBU 60 head/neck/torso phantom (Kyotokagaku Co., Ltd, Japan) in the position for the lateral imaging of the cervical spine (Cesar and Grkman, 2019)

We used a CR plate measuring $18 \mathrm{~cm} \times 24 \mathrm{~cm}$ that was placed in the wall tripod transversally. The radiograph shows the entire cervical spine and the first two thoracic vertebrae.

We changed the object to image receptor distance by $1 \mathrm{~cm}$ between the distances of the spinous process of the cervical vertebra from $24 \mathrm{~cm}$ to $39 \mathrm{~cm}$. Each change in the OID was imaged at three source to image receptor distances, i.e. 115 $\mathrm{cm}, 150 \mathrm{~cm}$ and $180 \mathrm{~cm}$.

At all OID and SID distances, we measured the size of the upper and bottom edge of the fifth cervical vertebra and calculated the magnification factor using the following formulas:

$$
\begin{gathered}
S O D=S I D-O I D \\
\text { object image size }
\end{gathered}
$$

ESD was measured at every OID and SID. ESD was calculated using the formula below:

$$
E S D=B S F \cdot Y \cdot\left(\frac{100}{S O D}\right)^{2} \cdot I t
$$

The output of the device $(Y)$, with which the measurements were performed, was $35.5 \mu \mathrm{Gy} / \mathrm{mAs}$ at SID of $100 \mathrm{~cm}$. The backscatter factor (BSF) equalled 1.33 at a field size of $20 \mathrm{~cm}$ $\times 20 \mathrm{~cm}$ (surface $400 \mathrm{~cm}^{2}$ ); we used a CR plate measuring 18 $\mathrm{cm} \times 24 \mathrm{~cm}$ in size (surface $432 \mathrm{~cm}^{2}$ ). Since there is no data for this value, we used the data of BSF at a field size $20 \mathrm{~cm} \times 20 \mathrm{~cm}$ for the calculation of ESD. For the calculation of the distance between the source and the point in the neck (source to object distance (neck)) where X-ray photons enter the patient's body, we subtracted SOD and the distance from spine to the edge of skin on the neck that was $6 \mathrm{~cm}$ from SID.

\section{RESULTS AND DISCUSSION}

\section{Vertebra size}

We measured the vertebra width while changing the OID from $24 \mathrm{~cm}$ to $39 \mathrm{~cm}$ at different SID. Figure 2 clearly shows that the vertebra width increased with a higher OID. At SID of $115 \mathrm{~cm}$, the vertebra size increased by $23 \%$, at $150 \mathrm{~cm}$ by $17 \%$ and at $180 \mathrm{~cm}$ by $11 \%$.

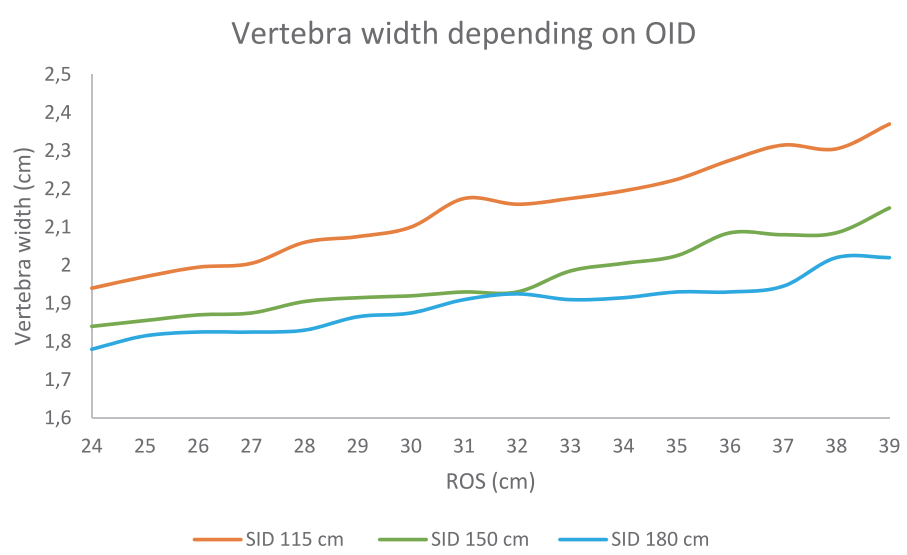

Figure 2: Illustration of vertebra width at a changing OID

We calculated the magnification factor. In theory, it can be calculated from SOD and SID. We determined that vertebrae increased by $24.9 \%$ when OID was increased from $24 \mathrm{~cm}$ to 39 $\mathrm{cm}$ at SID of $115 \mathrm{~cm}$, and by $16.1 \%$ and $12.3 \%$ at SID of $150 \mathrm{~cm}$ and $180 \mathrm{~cm}$, respectively. Figure 3 also shows that the curve is steeper at SID of $115 \mathrm{~cm}$ than at $150 \mathrm{~cm}$ and $180 \mathrm{~cm}$.

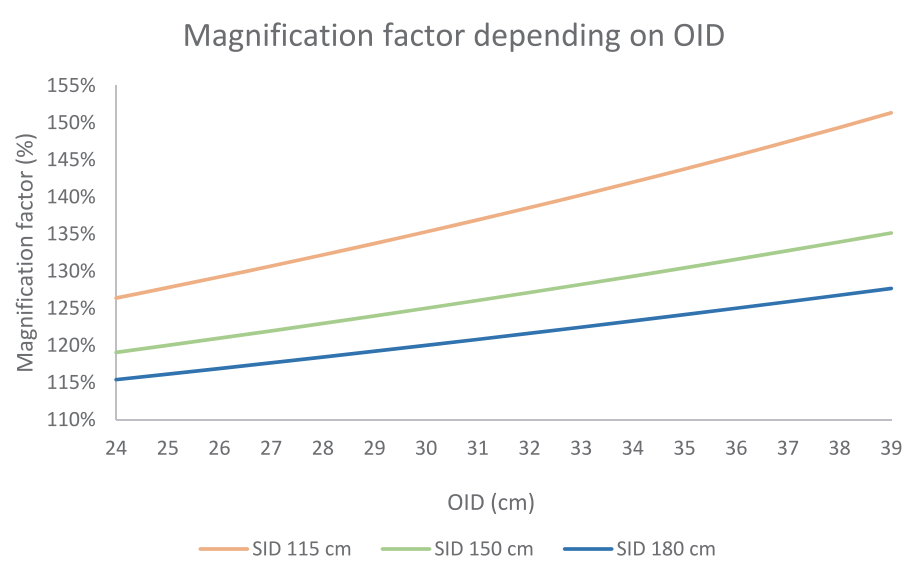

Figure 3: Magnification factor was calculated from SID and SOD

In practice, the magnification factor can be calculated from object size on a radiograph and natural object size. The difference in magnification factor when OID was increased 
from $24 \mathrm{~cm}$ to $39 \mathrm{~cm}$ at SID of $115 \mathrm{~cm}$ was $29 \%$, and $19.5 \%$ and $13 \%$ at SID of $150 \mathrm{~cm}$ and $180 \mathrm{~cm}$, respectively (Figure 4).

\section{Magnification factor depending on OID}

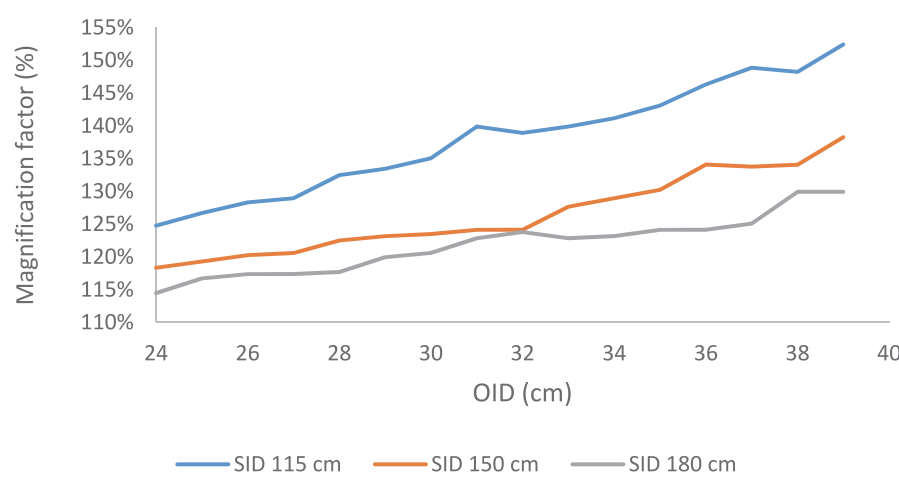

Figure 4: Magnification factor calculated from the natural size of vertebrae and the size of vertebrae on a radiograph

Table 1: Comparison of calculated magnification from SID and OID, and from the object image size and natural object size at a change in OID from $24 \mathrm{~cm}$ to $39 \mathrm{~cm}$

\begin{tabular}{|c|c|c|}
\hline $\begin{array}{c}\text { SID } \\
(\mathbf{c m})\end{array}$ & $\begin{array}{c}\text { SID/OID } \\
\text { (\%) }\end{array}$ & $\begin{array}{c}\text { Object image size / natural object size } \\
\text { (\%) }\end{array}$ \\
\hline $\mathbf{1 1 5}$ & 24.9 & 29.0 \\
\hline $\mathbf{1 5 0}$ & 16.1 & 19.5 \\
\hline $\mathbf{1 8 0}$ & 12.3 & 13.0 \\
\hline
\end{tabular}

If we compare the calculated magnification factors in terms of theory and practice, (Table 1) there are slight deviations. The difference is due to the fact that a precise measurement of the length of such a small object on the image is difficult due to the use of a computer mouse. It nevertheless provides information on the image size with an accuracy of a few millimetres. For a more accurate measurement, it would be necessary to count the number of pixels in the image.

There were two studies conducted regarding image magnification. They, however, provided contradictory results. Ravi and Rampersaud (5) discovered that there is a statistically significant correlation between the magnification of cervical vertebrae on a radiograph and body mass index. On the other hand, Shigematsu et al. (6) did not find a statistically significant correlation between the magnification of cervical vertebrae on the image and body mass index. If we want to compare our research to the aforementioned existing studies, we must presuppose that the body mass index grows with an increase in shoulder width, i.e. an increase in OID. We identified a correlation between the body mass index and magnification of cervical vertebrae on the image, as the magnification on the image was higher at an increased OID.

\section{Entrance skin dose}

Our aim was to determine the effect of OID and SID on the entrance skin dose. The ESD was calculated based on the product of current and time (mAs) that was recorded by the AEC system. When OID was increased from $24 \mathrm{~cm}$ to $39 \mathrm{~cm}$, the dose increased the most at SID of $115 \mathrm{~cm}$, i.e. by $66 \%$. At SID of $150 \mathrm{~cm}$, it increased by $42 \%$, and at $180 \mathrm{~cm}$ by $32 \%$. SID of $150 \mathrm{~cm}$ is used in practice for lateral imaging of the cervical spine. We calculated changes in ESD when SID was decreased to $115 \mathrm{~cm}$ and when it was increased to $180 \mathrm{~cm}$. Decreasing SID from $150 \mathrm{~cm}$ to $115 \mathrm{~cm}$, a slightly higher entrance skin dose enters the patient, while an increase in SID from $150 \mathrm{~cm}$ to $180 \mathrm{~cm}$ resulted in a slightly lower ESD entering the patient (Figure 5).

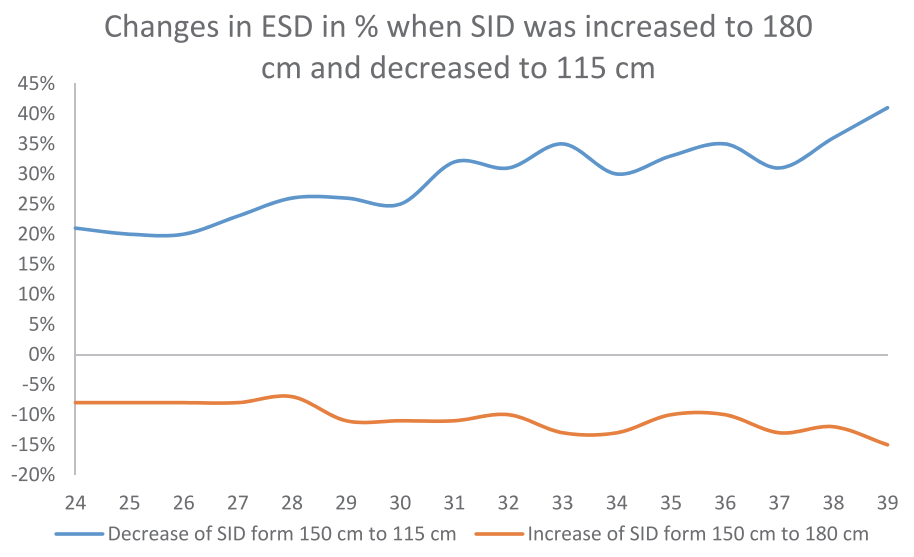

Figure 5: Changes in ESD in \% when SID was increased to $180 \mathrm{~cm}$ and decreased to $115 \mathrm{~cm}$

For practical applicability, OID between $24 \mathrm{~cm}$ and $39 \mathrm{~cm}$ was divided into three groups: narrow shoulder girdle $(24 \mathrm{~cm}$ to $29 \mathrm{~cm})$, middle shoulder girdle $(30 \mathrm{~cm}$ to $34 \mathrm{~cm}$ ) and broad shoulder girdle $(35 \mathrm{~cm}$ to $39 \mathrm{~cm})$. ESD decreased when OID was reduced and SID was increased. A decrease in SID from $150 \mathrm{~cm}$ to $115 \mathrm{~cm}$ for narrow shoulder girdle resulted in an increase in ESD by $26 \%$. The increase in ESD was $31 \%$ for middle shoulder girdle and $35 \%$ for broad shoulder girdle. An increase in SID from $150 \mathrm{~cm}$ to $180 \mathrm{~cm}$ for narrow shoulder girdle resulted in a decrease in ESD by $8.5 \%$. The decrease in ESD was $11.6 \%$ for middle shoulder girdle and $12.5 \%$ for broad shoulder girdle.

In order to evaluate our results, we compared them to two studies that measured the entrance skin dose. Automatic exposure control was used in all studies, while our research conditions differed in terms of the choice of imaging system and the characteristics of subjects. We used a CR system and a phantom simulating a $50 \mathrm{~kg}$ patient, while Zdešar et al. (10) used a film-reinforcing foil imaging system and an average patient weight of $74 \mathrm{~kg}$. The aforementioned differences resulted into deviations in ESD. The average ESD stated by Zdešar (10) was $0.98 \mathrm{mGy}$ at SID between $115 \mathrm{~cm}$ and $145 \mathrm{~cm}$. Our doses were significantly lower: ESD was $0.37 \mathrm{mGy}$ at SID of $115 \mathrm{~cm}, 0.29 \mathrm{mGy}$ at $150 \mathrm{~cm}$ and $0.26 \mathrm{mGy}$ at $180 \mathrm{~cm}$.

Joyce et al. (11) changed SID from $150 \mathrm{~cm}$ to $180 \mathrm{~cm}$ and $210 \mathrm{~cm}$, respectively. A flat panel detector, AEC system and accelerating voltage of $65 \mathrm{kV}$ were used. They determined that at an increase in SID from $150 \mathrm{~cm}$ to $210 \mathrm{~cm}$ resulted in a decrease in ESD by $37.4 \%$, while an increase in SID from $150 \mathrm{~cm}$ to $180 \mathrm{~cm}$ resulted in a decrease in ESD by $22.9 \%$. Our measurements showed that an increase in SID from $150 \mathrm{~cm}$ to $180 \mathrm{~cm}$ resulted in an average decrease in ESD by $11 \%$. For example, a decrease in SID from $150 \mathrm{~cm}$ to $115 \mathrm{~cm}$ resulted in an increase in ESD by $31 \%$. If we wish to compare our study to Joyce's (11), we only take into account the average values of ESD that were measured when SID was increased from 150 $\mathrm{cm}$ to $180 \mathrm{~cm}$. Deviations in results probably occurred due to a different accelerating voltage and detection system. 


\section{CONCLUSION}

The aim of our study was to determine the effect of SID and OID on the object distortion in an image. We were also interested in how different SIDs impact ESD.

We found during the research that an increase in SID resulted in a decrease in magnification in an image, while an increase in OID resulted in a bigger object size in the image. Increasing SID resulted in a reduction in a patient's ESD.

Measurements showed that lateral imaging of the cervical spine at SID of $150 \mathrm{~cm}$ is recommendable for two reasons. A higher SID results in a smaller object magnification on a radiograph, while we reduce the entrance skin dose for the patient, despite a higher product of current and time.

\section{REFERENCES}

1. Lipovec V, Mekiš N, Starc T (2016). Rentgenske slikovne metode in protokoli. Druga, dopolnjena izdaja. Ljubljana: Zdravstvena fakulteta, 5, 28 - 35, 265 - 268).

2. Bushong SC (2013). Radiologic Science for Technologists: physics, biology, and protection. 10th edition. St. Louis: Elsevier Mosby, 279 - 286.

3. Bushberg JT, Seibert JA, Leidholdt EM, Boone JM (2002). The essential physics of medical imaging, 2nd edition. Baltimore: Lippincott, Williams and Wilkins, 145 - 148.

4. Medič M, Mekiš N in Žibert J (2013). Radiološka tehnologija 1: učbenik za študente radiološke tehnologije. Ljubljana: Zdravstvena fakulteta, 165 - 194.

5. Ravi B, Rampersaud R (2008). Clinical magnification error in lateral spinal digital radiographs. Spine (Philia Pa 1976) 33(10): E311-6. doi: https://doi.org/10.1097/ BRS.0b013e31816f6c3f.

6. Shigematsu $H$, Koizumi $M$, Yoneda $M$, lida J, Oshima T, Tanaka Y (2013). Magnification Error in Digital Radiographs of the Cervical Spine Against Magnetic Resonance Imaging Measurements. Asian Spine Journal 7(4): 267-272. doi: 10.4184/asj.2013.7.4.267.

7. NRPB (1992). National Protocol for Patient Dose Measurements in Diagnostic Radiology. National Radiological Protection Board.

Accessible at: https://assets.publishing.service.gov.uk/ government/uploads/system/uploads/attachment_ data/file/337175/National_Protocol_for_Patient_Dose_ Measurements_in_Diagnostic_Radiology_for_website. pdf $<30.10 .2018>$.
8. Parry RA, Glaze SA, Archer BR (1999). The AAPM/RSNA Physics Tutorial for Residents. Typical Patient Radiation Doses in Diagnostic Radiology. Imaging \& Therapeutic Technology 19(5): 1289 - 1302.

Accessible at: https://pubs.rsna.org/doi/pdf/10.1148/ radiographics.19.5.g99se211289<20.3.2019>.

9. Quinn BC (2018). Radiography in the Digital Age: Physics, Exposure, Radiation Biology (Third Edition). Springfield: Charles C Thomas.

Accessible at: https://books.google.si/books?id= TGJbD wAA QBAJ\&pg=PA345\&dq=How+does+ESD+changes+ with+different+source+to+skin+distance\&hl=sl\&sa= X\&ved=0ahUKEwjP9IKw35DhAhUCposKHdBkAw MQ6AEIKjAA\#v=onepage\&q=How\%20does $\% 20$ ESD\%20changes\%20with\%20different\%20source \%20to\%20skin\%20distance\&f=false $<20.3 .2019>$.

10. Zdešar U, Rainer S, Pori D, Štuhec M (2000). Obsevanost pacientov pri klasičnih radioloških preiskavah v Splošni bolnišnici Slovenj Gradec. Poročilo raziskovalne naloge. Ljubljana, ZVD, 22

Accessible at: http://www.zvd.si/media/medialibrary /2010/11/sbsg-kd.pdf <30.10.2018>.

11. Joyce M, Brennan PC, Rainford LA, Last J, Ryan JT (2008). Impact on image quality when a variety of $X$-ray source detector distances are considered for the arthritic cervical spine. Proc. of SPIE Vol. 6913, 69135B.

Accessible at: https://www.researchgate.net/publication /252458429_Impact_on_image_quality_when_a_ variety_of_X-ray_source_detector_distances_ are_considered_for_the_arthritic_cervical_spine $<31.10 .2018>$.

12. DIMOND III (2004). Chapter III - Diagnostic requirements for digital projection radiography. Final report, 30.

Accessible at: https://www.sorf.fi/doc/diamond_Ill.pdf $<30.10 .2018>$. 